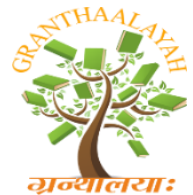

INTERNATIONAL JOURNAL OF RESEARCH GRANTHAALAYAH A knowledge Repository

Science

\title{
BUYING AND SELLING USED CLOTHING IN THE MARKET OF GEDE BAGE BANDUNG IN THE PERSPECTIVE OF ISLAMIC LAW AND LAW NO. 7 OF 2014 CONCERNING TRADE
}

\author{
Yuyut Prayuti *1 \\ ${ }^{* 1}$ Faculty of Law, Universitas Islam Nusantara, Bandung, Indonesia
}

\begin{abstract}
The purpose of this study is to analyze Islamic Law and Law No. 7 of 2014 concerning Regulations against the Sale and Purchase of Used Clothing at Gede Bage Market, Bandung. Data collection techniques were taken through observation and interviews. Furthermore, the data collected is compiled and analyzed using descriptive analysis method. The results of the study concluded that the practice of buying and selling used clothing at the Gede Bage Market in Bandung is almost the same as the practice of buying and selling in general. Products traded are clothes, shirts, shirts, only in the process of buying and selling, the seller does not provide information about the condition and status of the goods being sold. According to Islamic law in buying and selling used clothing is permitted if the buyer indirectly knows that the goods sold are used clothing, because clothes sold in the scope of ordinary shops and prices are relatively cheaper. Buying and selling is not allowed if the buyer really does not understand the condition of the seller because in this case including tadlis (fraud). Whereas according to the Trade Law concerning imported goods which are not new or used clothing that has violated the Trade Law are contained in article 47 paragraph 1. So that according to the Trade Law the imported goods are not new or used clothing is subject to sanctions according to article 111, namely imprisoned for a maximum of 5 (five) years or a maximum fine of Rp.5,000,000,000.00 (five billion rupiah).
\end{abstract}

Keywords: Used Clothing; Buying and Selling; Trading; Fraud; and Importing.

Cite This Article: Yuyut Prayuti. (2019). "BUYING AND SELLING USED CLOTHING IN THE MARKET OF GEDE BAGE BANDUNG IN THE PERSPECTIVE OF ISLAMIC LAW AND LAW NO. 7 OF 2014 CONCERNING TRADE." International Journal of Research Granthaalayah, 7(12), 224-230. https://doi.org/10.29121/granthaalayah.v7.i12.2019.315.

\section{Introduction}

Humans as social creatures are required to help each other in terms of helping, helping, interacting, loving and socializing with one another. As social creatures, human beings must provide assistance to their fellow human beings who are deemed incapable, all for the sake of perfecting and strengthening the kinship to their fellow humans. God commands his people to try to help one 
another in terms of goodness, not help in bad things that violates God's decrees and will be tormented in this world and the hereafter.

One form of business carried out by humans to make ends meet is to carry out a form of business or trade practice which generally involves buying and selling goods or services which in Islamic trade are described in three forms, namely Tijarah (trade), Bay '(Seller), Shira '(bought). The basic principles established by Islam regarding trade are the benchmarks of honesty, trust and sincerity.

Buying and selling is one form of business (trading or pilgrimage) which aims to make a profit. Buying and selling is a public contract that is often used by the community, because in every fulfillment of their needs, the community cannot turn to leave this contract [1]. To get food and drink, for example, sometimes he is unable to meet these needs by himself, but will need and connect with others, so it is likely to form a sale and purchase agreement [2].

In buying and selling, the important thing to show is to look for halal goods and in a halal way too. That is, look for halal goods to be traded or traded in an honest manner [3]. Clean from all traits that can damage the sale and purchase, such as fraud, theft, robbery, usury and others. if the goods being traded are not in accordance with the abovementioned, it means that they do not heed the rules of sale and purchase, actions and sale and purchase of goods that are carried out illegally, are forbidden to use and are forbidden to be eaten because they are classified as vanity (illegitimate) [4].

Buying and selling is a necessity for humans, the need to provide for their lives in the world of needs with all what is needed With this buying and selling, humans are required to have interaction with each other makes it easier to help each other and exchange goods or objects that have value (benefits ) which is done on a voluntary basis. Islam does not incriminate the existence of buying and selling, Islam will provide convenience in this matter, provided that the sale and purchase meets the legal and predetermined legal requirements.

Buying and selling will be said to be valid if it meets the terms and conditions, according to Rachmat Syafi'i 'there are four pillars, namely, bai' (seller), mushtari (buyer), sighat (consent and Kabul), ma'qud ' alaih (objects or items) [5]. In buying and selling there are limitations that must be considered, namely: a) Buying and selling tadlis. Buying and selling tadlis is buying and selling which contains a thing that is not known by either party; b) Buying and selling mulaqih. Buying and selling mulaqih is buying and selling where the goods are in the form of animals that are still in male seedlings before copulating with females; c) Buying and selling mudamin. Mudamin sale and purchase is the sale and purchase of animals that are still in the stomach of its mother. Buying and selling is not allowed by religion, because the goods are still unknown; d) Buying and selling muhaqalah. The sale and purchase of muhaqalah is the sale and purchase of fruits that have stems and are not yet suitable for consumption. The law is not allowed [6].

The elements of the sale and purchase agreement due to the presence of goods and prices. The sale and purchase agreement has existed since the agreement occurred on the goods and prices. Once between the two agreed or agreed, then there was a valid agreement [7]. For people who have entered the entrepreneurial world, it is obliged to know all the rights that can result in buying and selling is legal or not. This is intended so that it runs lawfully and its actions away from damage. 
Indonesia is a state of law, for that every trading business actor has rules or laws or also the rights and obligations in the sale and purchase business stipulated in RI law No. 7 of 2014 concerning trade. So that the seller and buyer know the extent of the rights and obligations between each seller and buyer.

Therefore, the researcher raised a problem which is now rife and the season for imported secondhand clothing. The imported goods must first be known when entering Indonesia through customs. Are the imported goods feasible or not traded in Indonesia? Whereas in Law on Trade No. 7/2014, Article 47 paragraph (1) which reads: "Every importer is obliged to import goods in new condition". In the prohibition of trading used clothing will not conflict with Law No. 8 of 1999 concerning Consumer Protection, wherein in the Law contained in article 8 paragraph (2) which reads: "Business actors are prohibited from trading damaged, defective or used and polluted goods without providing complete and correct information on the said items".

Particularly in the Bandung area, there have been many clothes shopping places that we have met and visited. One of the shopping places frequented by the public is Gede Bage market, inside the market there are many shops that sell clothes, Muslim clothing, shoes, bags and others. The procedure for buying and selling in this shopping center is to do a little cheating on consumers, if there are defective goods the seller pretends not to know, and if asked by consumers or buyers with second hand or second hand clothing questions then the seller also answers it with that these clothes are washing the warehouse.

Gede Bage market is known for its market that provides used clothing imports. The prices they sell vary and are not always the same depending on the model and material. The price they charge ranges from Rp. 15,000 to Rp. 100,000 Once a consumer entered the store, just call it RA, RA is a mother who intends to buy clothes at one of the shops in Gede Bage market, then when RA's mother asked the seller whether this is used clothes? Then the seller answers the question from RA's mother that this is not used clothing but imported goods from our warehouse, the goods are also taken from Jakarta.

Business actors who carry out buying and selling of used clothing imported goods have harmed consumers. Especially for ordinary people who when buying imported goods used because they do not know whether these imported goods are used clothing or not? all he knows is good models and more affordable prices. Judging from the situation like that, it is very possible that unfair business competition occurs and is not in accordance with the established rules. If such conditions are not immediately well anticipated, then the practice of oppression will emerge by those who have capital from the weak.

The reason is why to take Gede Bage market as an object of research based on the fact that the place is a place for buying and selling goods in new condition or well-known clothes, clean clothes, not leftover clothes or clothes that people wear. For this reason, a research or observation is needed on the practices carried out by the trading business community in Gede Bage market.

If it is true that the import of used clothing is prohibited from entering Indonesia, then from the agent, then the receipt of goods until the shipment of imported used clothing is immediately 
terminated so that the import of used clothing is not continuously enforced. On the other hand, in addition to profit and turnover income, which is getting higher and higher and the impact also occurs on consumers who feel disadvantaged.

\section{Method}

This type of research is field research that intends to study intensively about the current background and social interaction, individuals, groups, institutions and society. Data sources are all information used as respondents or originating from documents in the form of statistics or in other forms for the purposes of the research, including: a) Primary Sources: i.e. the first sources obtained through procedures and data collection techniques in the form of interviews, observation, as well as the use of special instruments designed in accordance with their objectives; b) Secondary sources, namely those obtained from indirect sources which are usually in the form of documentation data and official archives. To obtain the data needed in research, the researchers used data collection techniques by observing, interviewing and documenting. Meanwhile, the data analysis technique in this research is to use descriptive analysis method [8].

\section{Results and Discussions}

\section{Practice of Buying and Selling Used Clothing}

The practice of buying and selling used clothing that occurs in the Gede Bage Market in Bandung is no different from the implementation of the practice of buying and selling in general. Though this is evidenced by the pillars that are met, such as the pillars that are met by the seller and buyer who meet each other in person, evidence of goods traded, there is a greeting at the time of delivery of goods to the buyer and acceptance to the seller, consent and qabul at the time conduct transactions of buying and selling used clothing at Gede Bage market, Bandung, which is ongoing between the seller and the buyer as agreed between the two parties.

In the practice of buying and selling used clothing, in addition to meeting the conditions of sale and purchase, the conditions are also fulfilled in accordance with Islamic teachings, this shows that the requirements of the buyer must be mature and understandable, there is a consent and qabul spoken in making transactions when the sale and purchase takes place, the goods must be their own property, both parties know each other when entering into a contract.

\section{Analysis of Islamic Law and Law No. 7 of 2014 concerning Trade}

\section{Analysis of Islamic Law on the Practice of Buying and Selling Used Clothing}

Islamic law is a law that is based on rules in accordance with Islamic law, which is sourced from the arguments in Islamic teachings. As what has been stated, tadlis in buying and selling. According to Suhendi [9] that covering the disgrace of goods and what happened between the seller and the buyer. The seller can be said to commit fraud (tadlis) if hiding a defect in his merchandise without the knowledge of the buyer. Buyers can also be said to commit fraud (tadlis) if they manipulate payment instruments against the seller.

In the case of buying and selling transactions as for harmony and the conditions of sale and purchase that must be met include: a) Seller and Buyer, the conditions of the seller and buyer must 
be adults with reason and age, not children; b) Consent and qabul, contract (transaction) of all actions taken by both parties that indicate that they are carrying out transactions, both actions in the form of words and in the form of deeds; c) Goods or objects that are traded must be available [10].

The conditions of consent and qabul according to fiqh scholars are: a) Willingness from both parties; b) People who say consent and qabul have been puberty and understanding; c) Qabul in accordance with permission [11]. For example, the seller says: "I sell these clothes for ten thousand," Then the buyer replies: "I bought for ten thousand. "If the consent and qabul are not appropriate then the sale and purchase is not valid; d) consent and qabul is done in one majlis (place). That is, both parties who make buying and selling are present and discuss the same topic.

The practice of buying and selling used clothing at the shop used as the object of research is also in accordance with the terms and conditions, they make a contract (transaction) or consent and qabul in one place, they say consent and qabul which in essence has stated selling and buying goods, when say the contract must also be perfect if it is not perfect then the contract will be canceled. In carrying out a contract, they must face each other, when saying consent and qabul must mention the goods and price, when saying sighat (speech) must be accompanied by intention.

In the practice of buying and selling used clothing at the Gede Bage Market in Bandung, as stated above, this is a practice in the quality setting. Because in the practice of buying and selling there is unclear information that causes uncertainty, from interviews and researchers obtained from the buyer. In the practice of buying and selling used clothing that occurs, in fact the goods sold and then bought by customers are used clothing that is not suitable for sale because the clothes are leftout clothing worn by people and the clothes contain a lot of bacteria that can cause disease. However, the way they work is that they answer from customers 'or consumers' questions that the clothes purchased are imported goods from foreign warehouses, old goods or items from boutiques. even though the clothes on display are sometimes found defective.

If by the way of working like that, the practice of buying and selling carried out so it is not in accordance with Islamic legal norms, in the Koran mentioned as in the An-Nisa 'verse 29 which means "O people of faith, don't you ever eat your neighbor's property in a vanity way, except by the way of trade that applies with equal love between you and do not kill yourself. Verily Allah is Most Merciful to you ". The vanity side of the fact of the practice of buying and selling used clothing imported goods at Bandung's Gede Bage Market as described above is about dishonesty to the seller who hides about the condition or quality of the goods sold and then is handed over to the buyer. In this way, one can get a large profit from the results of the work done, while the buyer himself loses. Although what they actually do is based on like and liking, the quality of the practice that is practiced makes a flaw from the application of the principle in law.

If the buyer knows that the goods purchased are imported secondhand clothing, then the buyer is like a layman, he will not want to buy them, at least he is not willing to buy at a price already priced, because what is being sold is second-hand clothes, even if the goods purchased are still in good condition. But there is also what is revealed from the book of al-Mughni revealed by Ibn Qudamah, the Hanbali-based figure mentioned, that there is no difference in opinion of scholars about the ability to use imported clothing from non-Muslims [12]. According to Ibn Qudamah, if 
the clothes were not clothes or clothes worn in the body then it would not be a matter of using them. The law of used clothes is sacred, for example, accessories worn on the head such as hats, scarves and scarves. Imam Ahmad said, if the clothes were in the form of pants or inner and lower clothes, then it would be better for the person to repeat his prayer again with different clothes. According to Imam Shafi'i, used clothes that are imported are makruh. But Ibn Qudamah commented and underlined when the concerned was really sure of the sanctity of the clothes then it did not matter to wear the clothes. In this context and condition, the law is the same as Muslim dress [13].

\section{Analysis of Law No. 7 of 2014 concerning Trade in the Sale and Sale of Used Clothing}

In Law No. 7 of 2014 concerning trade the government has regulated the actions that have been banned for businesses against consumers to sell used clothing imports. One of them is contained in article 47 of the Trade Law which contains four paragraphs: 1) Every Importer is obliged to import goods in a new condition; 2) In certain cases the Minister can determine imported goods in a new condition; 3) Determination as referred to in paragraph (2) shall be submitted to the minister who carries out government affairs in the financial sector; 4) Further provisions regarding the determination of imported goods in a new condition as referred to in paragraph (2) shall be regulated by ministerial regulation.

In the matter of importing used clothing, this is more appropriate with the trade law in article 47 paragraph 1. In this case, who has violated the law and may be subject to sanctions, namely: 1) If it has violated the sanctions contained in article 46;2) Importers are fully responsible for imported Goods; 3) Importers not responsible for imported goods as intended in paragraph (1) are subjected to administrative sanctions in the form of revocation, approval, recognition, or stipulation in the trade sector; 4) Further provisions regarding the procedure for imposing administrative sanctions as referred to in paragraph (2) shall be regulated in a Ministerial Regulation.

There is also article 111 for the criminal provisions that read: "Every importer who imports goods in a new condition as referred to in article 47 paragraph (1). In a criminal case with a maximum imprisonment of 5 (five) years or a maximum fine of Rp.5,000,000,000.00 (five billion rupiah)". So according to the trade law on imported goods that are not new, including used clothing, it can be subject to sanctions contained in article 111 of the sentence in a criminal sentence with a maximum imprisonment of 5 (five) years or a maximum fine of Rp.5,000,000,000.00 ( Five billion Rupiah). In the law of trade in goods that are not in a new condition, it has been explained that in accordance with article 47 paragraph (1) since its duration, but to reinforce the prohibition of import of used clothing also already exists in the trade ministry regulations contained in number 51 / M-DAG / PER / 7/2015 [14].

For this reason, it also applies to the consumer protection legislation for business actors regarding the information on goods traded contained in Article 8 paragraph (1) which reads: "Business actors are prohibited from trading goods that are damaged, defective or used, and polluted without providing full information. and true of the intended item". The act of prohibiting entry of non-new or imported used clothing has allegedly contained many harmful bacteria and viruses and this has been laboratory tested. This is an appeal for businesspeople to immediately end up selling used clothing imported goods and prioritize for the health of consumers. 


\section{Conclusion}

The practice of buying and selling used clothing at the Bandung Gede Bage Market, there are several shops that hide some information about the conditions of the imported used clothing. The practice of buying and selling used clothing that occurs at Gede Bage. According to Islamic law it is permissible but there is cheating from sellers which results in fraudulent buying and selling activities. In the word of God that in buying and selling activities are not allowed to carry out commercial activities by vanity but must be based on the willingness of the two of them, namely the seller and buyer. The regulations on used clothing imported goods have been banned according to positive law because they are suspected to contain bacteria and viruses, the prohibition of selling used clothing imported goods has also been regulated by the ministry of trade with no. $51 / \mathrm{M}$ DAG / PER / 7/2015. Not only from the Ministry of Trade which prohibits but for a long time Law no. 7 of 2014 also prohibits those contained in article 47 paragraph (1) that imported goods must be in a new condition. Of these regulations there are also administrative sanctions and other sanctions and criminal laws.

\section{References}

[1] Muhammad Djakfar, Hukum Bisnis (Membangun Wacana Integritas Perundangan Nasional dengan Syariah) (Malang: UIN-Malang: 2009).

[2] Dimyauddin Djuwaini, Pengantar Fiqh Muamalah (Yogyakarta: Pustaka Pelajar, 2008).

[3] Ibnu Mas'ud, Zainul Abidin S, FIQIH Madzhab Syafi'I Buku 2 (Bandung: Pustaka Setia, 2007).

[4] Mardani, FIQIH Ekonomi Syariah (Jakarta: Kencana, 2012).

[5] Rachmat Syafe'I, Fiqh Muamalah (Bandung: CV Pustaka Setia, 2006).

[6] Abdul Aziz Muhammad Azzam, Fiqih Muamlah (Jakarta: Amzah, 2010).

[7] Muhammad Djakfar, Hukum Bisnis, (Membangun Wacana Integritas Perundangan Nasional dengan Syariah) (Malang: UIN-Malang).

[8] Riyanto, Adi. Metode Penelitian social dan Hukum. Jakarta: Granit. 2004.

[9] Suhendi, Hendi. Fiqh Muamalah. Jakarta: PT Raja Grafindo. 2002.

[10] Dimayuddin, Djuwaini. Pengantar Fiqh Muamalah. Yogyakarta: Pustaka Pelajar. 2008.

[11] Dahlan, Abdul Aziz. Ensiklopedi Hukum Islam Cet. VII. Jakarta: PT Ichtiar Baru Van Hoeve. 2006.

[12] Mashud. Tinjauan Hukum Islam Terhadap Jual Beli Pakaian Bekas dalam karung (balbalan) di kawasan Gembong Tebasan Surabaya Skripsi: IAIN Sunan AmpelSurabaya. 2011.

[13] Ghazaly, Abdul Rahman dkk. Fiqih Muamalat. Jakarta: Kencana. 2010.

[14] Jannah, Eka Zamrotul. Praktek Jual Beli Barang Cacat di Pasar Pegirian Surabaya dalamPersepektif Hukum Islam dan Undang-undang RI No. 8 Tahun 1999 TentangPerlindungan Konsumen, skripsi: IAIN Sunan Ampel Surabaya. 2006. 